\title{
Technical Parameters Affecting the Spray Drying of Roselle (Hibiscus Sabdariffa) Powder
}

\author{
Nguyen Phuoc Minh \\ Faculty of Food Science and Technology, Thu Dau Mot University, Binh Duong Province, Vietnam.
}

\begin{abstract}
Roselle (Hibiscus sabdariffa) was a member of Malvaceae family. Its calyxes had bright red color due to presence of anthocyanin with an excellent antioxidant property. Raw roselle (Hibiscus sabdariffa L.) calyx was highly perishable due to its high moisture content. In order to diversify products from this plant, this research evaluated the possibility of spray drying for roselle extract into dried powder for long-term consumption. We focused on the effect of sugar alcohols (mannitol, sorbitol, isomalt, xylitol, erythritol) at $\mathbf{8 \%}$, carrier agents (maltodextrin, gum arabic, glutinous starch, whey protein concentrate, carboxymethyl cellulose) at $12 \%$, operating parameters of spray dryer (inlet/outlet air temperature, feed rate) on physicochemical quality (bulk density, solubility, total phenolic content, total flavonoid content, anthocyanin content) of rosselle powder. Results showed that the optimal spray drying variables for rosselle powder should be $8 \%$ isomalt, $12 \%$ whey protein concentrate, inlet/ outlet air temperature $140 / 85^{\circ} \mathrm{C} /{ }^{\circ} \mathrm{C}$, feed rate $12 \mathrm{ml} / \mathrm{min}$. Based on these optimal conditions, the highest physicochemical attributes of the dried roselle calyx powder would be obtained.
\end{abstract}

Keywords: Anthocyanin, carrier agent, operating parameter, physicochemical, Roselle calyx, sugar alcohol

*Correspondence: nguyenphuocminh@tdmu.edu.vn

(Received: October 19, 2020; accepted: December 07, 2020)

Citation: Minh NP. Technical Parameters Affecting the Spray Drying of Roselle (Hibiscus Sabdariffa) Powder. J Pure Appl Microbiol. 2020;14(4):2407-2416. doi: 10.22207/JPAM.14.4.18

(C) The Author(s) 2020. Open Access. This article is distributed under the terms of the Creative Commons Attribution 4.0 International License which permits unrestricted use, sharing, distribution, and reproduction in any medium, provided you give appropriate credit to the original author(s) and the source, provide a link to the Creative Commons license, and indicate if changes were made. 


\section{INTRODUCTION}

Spray drying was widely utilized in food industry to preserve thermal-sensitive phytochemical constituents in herbs, vegetables and fruits in which solvent mixture was sprayed and transformed into crystallize substances with appropriate attributes ${ }^{1-10}$. The degree of crystallization was accelerated when the moisture content was reduced and when the concentration of solid material was increased ${ }^{3,11,12}$. Spray dried powder was convenient for handling and distribution by its light weight ${ }^{13}$. Water mobility in the food matrix caused changes of physicochemical, microbial and nutritional properties of spray dried powder ${ }^{13,14}$. Moisture was commonly absorbed into spray dried powder under preservation. Spray drying would become an ideal approach if the shelf life of the powder was extended and the antioxidant elements in material extract could be preserved during production, and if the contacting surface area could be extended ${ }^{15}$. Roselle (Hibiscus sabdariffaL.) calyx drawed a special attention due to its nutritional composition, bioactive constituents and therapeutic applications ${ }^{16}$. Extract from roselle calyces had unique pigment by the existing of anthocyanin with high antioxidant properties ${ }^{17,18}$. It's beneficial to relieve hypertension, hyperlipidemia, cancer and inflammatory diseases ${ }^{19}$. It's also demonstrated to mild the blood viscosity, stimulate milk release and induce intestinal peristalsis ${ }^{20-22}$. Roselle (Hibiscus sabdariffa L.) calyx commonly utilized to convert into value added products like wine, syrup, juice, jam, jelly, pudding, cake, ice cream, tea, confectionary, sauce, marmalade, chocolate, flavouring agent ${ }^{16,23-31}$. There were several notable reports mentioned to the processing of roselle calyx. The influences of input air temperature and feed rate on the powder quality attributes during spray-drying of roselle extract were examined ${ }^{29}$. Various variables in production of dried Roselle (Hibiscus sabdariffa L.) calyx herbal tea were investigated ${ }^{16}$. Archaina et al..$^{32}$ maintained the antioxidant ability and enhanced the shelf life of spray-dried roselle powder by incorporation of maltodextrin and gum arabic as wall material. Al-Kahtani $\mathrm{HA}$ and Hassan $\mathrm{BH}^{33}$ manufactured spray-dried powder from extract of roselle (Hibiscus sabdariffa) calyces. Gonzalez-Palomares et al. ${ }^{34}$ verified different drying temperatures on the volatile substances and organoleptic property of the roselle (Hibiscus sabdariffa) powder. Mohamad et al. ${ }^{35}$ examined the the influence of air temperature of foam mat drying on the kinetics and quality of dehydrared roselle extract. Cid-Ortega and Guerrero-Beltran ${ }^{36}$ verified the microencapsulation of Hibiscus sabdariffa (roselle) extract by spray drying with the support of maltodextrin and gum arabic as wall material. Navidad-Murrieta et al. ${ }^{37}$ demonstrated the effect of maltodextrin and gum arabic as carrier material in spray-drying of Hibiscus sabdariffa extract. Objective of our study to examine the effect of sugar alcohols (mannitol, sorbitol, isomalt, xylitol, erythritol), carrier agents (maltodextrin, gum arabic, glutinous starch, whey protein concentrate, carboxymethyl cellulose), operating parameters of spray dryer (inlet/outlet air temperature, feed rate) on physicochemical quality (bulk density, solubility, total phenolic content, total flavonoid content, anthocyanin content) of rosselle powder.

\section{MATERIAL AND METHOD Material}

Hibiscus sabdariffa calyces were collected in Soc Trang province, Vietnam. Fully bloomed, disease free, and undamaged healthy calyces were chosen. They were washed under clean water to remove foreign matters. Chemical reagents such as FolinCiocalteu's reagent, $\mathrm{NaHCO}_{3}$, gallic acid, $\mathrm{AlCl}_{3}$, methanol, quercetin were all analytical grade purchased in Ho Chi Minh city, Vietnam. Powder was obtained by using a mini spray dryer.

\section{Researching method}

Hibiscus sabdariffa calyces were primarily frozen-thawed, twice pressed and extracted by hot water in ratio 1: 4 (material: water, w/v) at $90^{\circ} \mathrm{C}$ for 15 minutes. The mixture was passed through vacuum filter to collect extract.

\section{Experiment \#1}

The Hibiscus sabdariffa extract was added with $8 \%$ sugar alcohols (mannitol, sorbitol, isomalt, xylitol, erythritol) before undergoing spray drying process by $12 \%$ maltodextrin as carrier agent, inlet temperature $130^{\circ} \mathrm{C}$, outlet temperature $75^{\circ} \mathrm{C}$, feed rate $8 \mathrm{ml} / \mathrm{min}$.

\section{Experiment \#2}

The Hibiscus sabdariffa extract was added $8 \%$ isomalt plus $12 \%$ carrier agents (gum arabic, maltodextrin, modified starch, whey 
protein concentrate, carboxy methylcellulose). This mixture was ready for spray drying at inlet temperature $130^{\circ} \mathrm{C}$, outlet temperature $75^{\circ} \mathrm{C}$, feed rate $8 \mathrm{ml} / \mathrm{min}$.

\section{Experiment \#3}

The Hibiscus sabdariffa extract was added $8 \%$ isomalt plus $12 \%$ whey protein concentrate. The spray dryer conducted at different inlet/ outlet air temperature $(130 / 75,135 / 80,140 / 85$, $145 / 90,150 / 95,{ }^{\circ} \mathrm{C} /{ }^{\circ} \mathrm{C}$ ) at feed rate $8 \mathrm{ml} / \mathrm{min}$. After choosing the appropriate inlet/outlet air temperature, the spray drying process also verified the effect of different feed rate $(8,10,12,14,16$ $\mathrm{ml} / \mathrm{min}$ ).

The target functions in each experiment were based on bulk density $(\mathrm{mg} / \mathrm{ml})$, solubility (\%), total phenolics (mg GAE/ $100 \mathrm{~g}$ ), total flavonoids (mg QE/ $100 \mathrm{~g}$ ), anthocyanin (mg/ $100 \mathrm{~g}$ ) of the spray-dried powder.

\section{Physicochemical evaluation}

Bulk density $(\mathrm{g} / \mathrm{ml})$ and the solubility $(\%)$ were determined by procedures described by Saikia et al. ${ }^{7} \mathrm{~A} 5 \mathrm{~g}$ of dehydrated sample was poured into a $50 \mathrm{~mL}$ graduated cylinder, and measured the line fullfilled by the powder as bulk density. $5 \mathrm{~g}$ powder was disolved with distilled water at a ratio of 1:9. The fluid was then separated by centrifugator at $3,500 \mathrm{rpm}$ within 4 minutes. The supernatant was obtained, dehydrared and measured the weight. The solubility (\%) was estimated by dividing the weight of supernatant after dehydration by the weight of primary powder, multiplying with 100. Total phenolic (mg GAE/100g) content was determined using spectrophotometric method ${ }^{38}$. $5 \mathrm{ml}$ of methanol was mixed with $5 \mathrm{~g}$ powder,
$25 \mathrm{ml}$ of $9.5 \%$ FolinCiocalteu's reagent dissolved in distilled water and $25 \mathrm{ml}$ of $7.0 \% \mathrm{NaHCO}_{3}$. The control sample was diluted, including $5 \mathrm{ml}$ methanol, $25 \mathrm{ml}$ of $9.5 \%$ Folin-Ciocalteu's reagent dissolved in distilled water and $25 \mathrm{ml}$ of $7.0 \%$ of $\mathrm{NaHCO}_{3}$. Samples were then incubated at $50^{\circ} \mathrm{C}$ for 20 minutes. The absorbance was recorded at $\lambda_{\max }=765 \mathrm{~nm}$ by a spectrophotometer. The similar protocol was conducted for the standard solution of gallic acid and the calibration line was established. Read on the absorbance value, the total phenolic concentration was calculated from the calibration curve; the total phenolic concentration was presented as a gallic acid equivalence ( $\mathrm{mg}$ of $\mathrm{GAE} / 100 \mathrm{~g}$ of sample). Total of flavonoids (mg QE/100g) was examined using spectrophotometric technique ${ }^{39} .25$ gram of powder was extracted with $5 \mathrm{ml}$ of methanol with the presence of $5 \mathrm{ml}$ of $2.5 \% \mathrm{AlCl}_{3}$ solution. The samples were kept for 1.5 hours at ambient condition. This mixture was incubated for 25 minutes at ambient condition. The absorbance was verified at $\lambda_{\max }=415 \mathrm{~nm}$ by a spectrophotometer. The similar protocol was prepared for the standard solution of quercetin and the calibration graph was established. Read on the calculated absorbance, the flavonoid concentration was calculated (mg/ $\mathrm{mL}$ ) from the calibration curve and the flavonoid concentration was presented as a term of quercetin equivalent (mg of $\mathrm{QE} / 100 \mathrm{~g}$ of sample). Anthocyanin content $(\mathrm{mg} / 100 \mathrm{~g})$ was determined by spectroscopy at wavelength $530 \mathrm{~nm}^{40}$.

\section{Statistical summary}

The demonstrations were prepared in 3 times for various sample groups. The values were

Table 1. Effect of sugar alcohols (8\%) on physicochemical property of Hibiscus sabdariffa powder

\begin{tabular}{lccccc}
\hline Sugar alcohols & Mannitol & Sorbitol & Isomalt & Xylitol & Erythritol \\
\hline Bulk density (g/ml) & $0.29 \pm 0.01^{\mathrm{c}}$ & $0.36 \pm 0.00^{\mathrm{bc}}$ & $0.69 \pm 0.03^{\mathrm{a}}$ & $0.57 \pm 0.01^{\mathrm{ab}}$ & $0.48 \pm 0.02^{\mathrm{b}}$ \\
Solubility (\%) & $48.75 \pm 0.03^{\mathrm{c}}$ & $52.68 \pm 0.02^{\mathrm{bc}}$ & $77.42 \pm 0.01^{\mathrm{a}}$ & $69.83 \pm 0.00^{\mathrm{ab}}$ & $60.51 \pm 0.03^{\mathrm{b}}$ \\
$\begin{array}{l}\text { Total phenolic } \\
\text { (mg GAE/ 100 g) }\end{array}$ & $297.15 \pm 1.17^{\mathrm{c}}$ & $328.64 \pm 1.63^{\mathrm{bc}}$ & $487.50 \pm 1.52^{\mathrm{a}}$ & $401.27 \pm 1.19^{\mathrm{ab}}$ & $359.34 \pm 1.32^{\mathrm{b}}$ \\
$\begin{array}{l}\text { Total flavonoid } \\
\text { (mg QE/ 100 g) }\end{array}$ & $116.21 \pm 0.34^{\mathrm{c}}$ & $154.36 \pm 0.18^{\mathrm{bc}}$ & $224.67 \pm 0.23^{\mathrm{a}}$ & $201.42 \pm 0.17^{\mathrm{ab}}$ & $186.04 \pm 0.22^{\mathrm{b}}$ \\
$\begin{array}{l}\text { Anthocyanin } \\
\text { (mg/100g) }\end{array}$ & $79.83 \pm 0.11^{\mathrm{c}}$ & $93.68 \pm 0.07^{\mathrm{bc}}$ & $185.16 \pm 0.15^{\mathrm{a}}$ & $145.63 \pm 0.20^{\mathrm{ab}}$ & $119.71 \pm 0.07^{\mathrm{b}}$ \\
\hline
\end{tabular}

Figures are the mean of three replications; Figures in row followed by the same letter $/ \mathrm{s}$ are not differed significantly $(\alpha=\mathrm{P}=0.05)$. 
expressed as mean \pm standard deviation. Statistical summary was conducted by the software of Statgraphics XVI.

\section{RESULT AND DISCUSSION}

Effect of sugar alcohols on physicochemical property of Hibiscus sabdariffa powder

Table 1 presented the influence of different sugar alcohols (mannitol, sorbitol, isomalt, xylitol, erythritol) supplemented on physicochemical attributes of roselle calyx powder. Isomalt revealed the best candidate to replace saccharose as well as other sugar alcohols. Mannitol, the sugar alcohol stereoisomer of sorbitol, originated from starch or sugar by hydrogenation, by fermentation or by natural product extraction ${ }^{41-42}$. Mannitol, mildly acidic in aqueous solution, exhibited sweetness equal to glucose and half as sweet as sucrose. Mannitol played as an osmotic diuretic agent and weak renal vasodilator $^{43}$. Sorbitol had good compressibility and commonly utilized as a bulking agent ${ }^{44}$. Isomalt originated from sugar by fermentation of sucrose to isomaltulose and further hydrogenation of the reducing fructose moiety. Isomalt exhibited about half the sweetness of sucrose. Xylitol was prepared from hydrolyzation of xylan into xylose which was catalytically hydrogenated into xylitol. Xylitol had sweetness as sucrose and gave an excellent cooling effect. Erythritol was a 4-carbon sugar alcohol obtained by yeast fermentation of glucose or sucrose. Its sweetness was $80 \%$ relative to sucrose combined with the strongest cooling effect.

Bulk density was the weight of the solid components with water divided by the total volume fullfilled by the particles, layer moisture and all pores inside ${ }^{45}$. The advantge of powder obtained with high bulk density was that it could be kept in high amount into small container and vice versa ${ }^{15}$. At low moisture content, the spray dried powder was very easy to absord water in surrounding atmosphere to get sticky and inconvenient to manipulate ${ }^{15}$. At low bulk density, the high amount of air existed within the powder and more chance of powder oxidation and shorter preserved shelf life ${ }^{46}$. Low bulk density indicated in high space for packaging. Accelerating in bulk density was greatly related to moisture content absorbed and water activity built up ${ }^{47-48}$. The soluble capacity of powder was an important quality property of spray dried powders ${ }^{49}$. Solubility reflected the final quality of powder that could be brought into stable suspension ${ }^{50}$. Solubility was related to simplicity of reconstitution. Poor solubility happened especially at high temperature and high solid content. Functional solubility was highly affected by structural modification of the powder ${ }^{51}$. High concentration of drying agents induced to low solubility of the dried fruit powder ${ }^{52}$. The higher the solubility of powder, the lower the bulk density ${ }^{53}$. Solubility was one of major problems in the dried powder obtained from spray drying due to existing of low molecular weight sugars and acids ${ }^{54}$. Gum resulted in high solubility in aqueous solution facilitating the spray drying ${ }^{55}$. Anthocyanins were hydrophilic pigment specifically compatible with a water-based gel. Phenolics and flavonoids might created complexes with polysaccharides and the affinity of phenolics to polysaccarides depended on the water solubility, molecular

Table 2. Effect of carrier agents (12\%) on physicochemical property of Hibiscus sabdariffa powder

\begin{tabular}{|c|c|c|c|c|c|}
\hline Carrier agents & Gum arabic & Maltodextrin & $\begin{array}{l}\text { Modified } \\
\text { starch }\end{array}$ & $\begin{array}{c}\text { Whey } \\
\text { protein } \\
\text { concentrate }\end{array}$ & $\begin{array}{l}\text { Carboxy } \\
\text { methyl } \\
\text { cellulose }\end{array}$ \\
\hline Bulk density (g/ml) & $0.50 \pm 0.01^{\mathrm{bc}}$ & $0.69 \pm 0.03^{b}$ & $0.75 \pm 0.02^{\mathrm{ab}}$ & $0.84 \pm 0.01^{\mathrm{a}}$ & $0.39 \pm 0.02^{c}$ \\
\hline Solubility (\%) & $69.34 \pm 0.00^{\mathrm{bc}}$ & $77.42 \pm 0.01^{\mathrm{b}}$ & $80.17 \pm 0.03^{\mathrm{ab}}$ & $85.49 \pm 0.00^{\mathrm{a}}$ & $60.08 \pm 0.03^{c}$ \\
\hline $\begin{array}{l}\text { Total phenolic } \\
\text { (mg GAE/ } 100 \mathrm{~g} \text { ) }\end{array}$ & $443.18 \pm 1.45^{\mathrm{bc}}$ & $487.50 \pm 1.52^{b}$ & $501.23 \pm 1.64^{\mathrm{ab}}$ & $520.67 \pm 1.26^{a}$ & $401.24 \pm 1.32^{c}$ \\
\hline $\begin{array}{l}\text { Total flavonoid } \\
\text { (mg QE/ } 100 \mathrm{~g} \text { ) }\end{array}$ & $198.50 \pm 0.18^{\mathrm{bc}}$ & $224.67 \pm 0.23^{b}$ & $248.36 \pm 0.12^{\mathrm{ab}}$ & $271.52 \pm 0.17^{a}$ & $160.43 \pm 0.21^{c}$ \\
\hline $\begin{array}{l}\text { Anthocyanin } \\
\text { (mg/100g) }\end{array}$ & $160.24 \pm 0.21^{\mathrm{bc}}$ & $185.16 \pm 0.15^{b}$ & $201.13 \pm 0.09^{a b}$ & $229.54 \pm 0.15^{a}$ & $146.81 \pm 0.13^{c}$ \\
\hline
\end{tabular}

Figures are the mean of three replications; Figures in row followed by the same letter/s are not differed significantly $(\alpha=P=0.05)$. 
size, conformational mobility and structure of polyphenol. Anthocyanins and polyphenols were easy decomposed under thermal processing ${ }^{56}$.

Influence of carrier agents on physicochemical property of Hibiscus sabdariffa powder

Wall material agents significantly influenced the anthocyanin stability of roselle caly $\mathrm{x}^{57}$. Various carriers was used in spray drying of roselle to encapsulate anthocyanin such as pullulan ${ }^{58}$, trehalose and maltodextrin ${ }^{59}$, maltodextrin and gum $\mathrm{Arabic}^{60}$. Table 2 showed the influence of different sugar carrier agents on physicochemical attributes of roselle calyx powder. Among gum arabic, maltodextrin, modified starch and carboxymethyl cellulose; whey protein concentrate revealed the best option for spray drying roselle calyx powder (bulk density $0.84 \pm 0.01 \mathrm{~g} / \mathrm{ml}$, solubility $85.49 \pm 0.00 \%$, total phenolic $520.67 \pm 1.26 \mathrm{mg}$ GAE/ $100 \mathrm{~g}$, total flavonoid $271.52 \pm 0.17 \mathrm{mg}$ QE/ $100 \mathrm{~g}$, anthocyanin $229.54 \pm 0.15 \mathrm{mg} / 100 \mathrm{~g})$. Meanwhile, carboxymethyl cellulose resulted to the lowest physicochemical properties of roselle calyx powder (bulk density $0.39 \pm 0.02 \mathrm{~g} / \mathrm{ml}$, solubility $60.08 \pm 0.03 \%$, total phenolic $401.24 \pm 1.32 \mathrm{mg} \mathrm{GAE} /$ $100 \mathrm{~g}$, total flavonoid $160.43 \pm 0.21 \mathrm{mg} \mathrm{QE} / 100 \mathrm{~g}$, anthocyanin $146.81 \pm 0.13 \mathrm{mg} / 100 \mathrm{~g}$ ). Yousefi et al. ${ }^{45}$ examined maltodextrin, gum Arabic, waxy starch as carrier agent on on the physicochemical properties of pomegranate powder. Gum arabic revealed the most effective yield, bulk density and solubility. Cristhiane et al. ${ }^{61}$ examined the impact of maltodextrin, gum arabic on the physicochemical characteristics of blackberry powder produced by spray dehydration. Maltodextrin contributed to less water absorption of powder with low water activity and high dissolving attributes. Bhusari et al. ${ }^{62}$ examined influence of wall materials on physical and microtextural characteristics of spraydehydrated tamarind pulp powder. Whey protein concentrate revealed the best improvement of yield, color, bulk density and hygroscopicity. Tan and Thuy ${ }^{63}$ optimized maltodextrin and arabic gum during spray drying of Pouzolzia zeylanica extract. The optimum concentrations of $8.74 \%$ maltodextrin and $0.08 \%$ arabic gum were concluded. Varastegani et al. ${ }^{64}$ evaluated the influence of spray-drying with maltodextrin and gum arabic on antioxidant capability, ash, proximate and overall acceptance. Data revealed that spray-dehydrated powder had low caffeine and fat content, antioxidant activity. Meanwhile the ash of spray-dehydrated product strongly accelerated. Archaina et al. ${ }^{32}$ concluded that using maltodextrin-gum arabic as wall material resulted spray-dired roselle powder with excellent physical attributes such as low moisture content, low cohesiveness, high glass transition temperature, high solubility, good flowability. Cid-Ortega and Guerrero-Beltran ${ }^{36}$ verified the microencapsulation of Hibiscus sabdariffa (roselle) extract by spray drying with the support of maltodextrin and gum arabic as wall material. The best formula of carrier agent was noticed at $3 \%$ maltodextrin: gum arabic. Navidad-Murrieta et al. ${ }^{37}$ demonstrated the effect of maltodextrin and gum arabic as carrier material in spray-drying of Hibiscus sabdariffa extract. Results revealed that maltodextrin: gum arabic $(80: 20, \mathrm{w} / \mathrm{w})$ was appropriate to encapsulate and retain the most phenolics in Hibiscus

Table 3. Effect of inlet/ outlet temperature (oC) on physicochemical property of Hibiscus sabdariffa powder

\begin{tabular}{lccccc}
\hline $\begin{array}{l}\text { Inlet/ outlet temp. } \\
\left({ }^{\circ} \mathrm{C} /{ }^{\circ} \mathrm{C} \text { ) }\right.\end{array}$ & $130 / 75$ & $135 / 80$ & $140 / 85$ & $145 / 90$ & $150 / 95$ \\
\hline Bulk density (g/ml) & $0.84 \pm 0.01 \mathrm{~b}$ & $0.89 \pm 0.03 \mathrm{ab}$ & $0.93 \pm 0.00 \mathrm{a}$ & $0.77 \pm 0.02 \mathrm{bc}$ & $0.68 \pm 0.01 \mathrm{c}$ \\
Solubility (\%) & $85.49 \pm 0.00 \mathrm{~b}$ & $87.33 \pm 0.02 \mathrm{ab}$ & $90.04 \pm 0.03 \mathrm{a}$ & $80.25 \pm 0.00 \mathrm{bc}$ & $74.30 \pm 0.03 \mathrm{c}$ \\
$\begin{array}{l}\text { Total phenolic } \\
\text { (mg GAE/ 100 g) }\end{array}$ & $520.67 \pm 1.26 \mathrm{a}$ & $507.30 \pm 1.13 \mathrm{ab}$ & $484.12 \pm 1.37 \mathrm{~b}$ & $454.12 \pm 1.05 \mathrm{bc}$ & $423.07 \pm 1.18 \mathrm{c}$ \\
$\begin{array}{l}\text { Total flavonoid } \\
\text { (mg QE/ 100 g) }\end{array}$ & $271.52 \pm 0.17 \mathrm{a}$ & $234.39 \pm 0.23 \mathrm{ab}$ & $201.57 \pm 0.12 \mathrm{~b}$ & $180.03 \pm 0.14 \mathrm{bc}$ & $161.25 \pm 0.09 \mathrm{c}$ \\
$\begin{array}{l}\text { Anthocyanin } \\
\text { (mg/100g) }\end{array}$ & $229.54 \pm 0.15 \mathrm{a}$ & $197.30 \pm 0.11 \mathrm{ab}$ & $164.29 \pm 0.13 \mathrm{~b}$ & $120.74 \pm 0.08 \mathrm{bc}$ & $99.63 \pm 0.07 \mathrm{c}$ \\
& & & & &
\end{tabular}

Figures are the mean of three replications; Figures in row followed by the same letter/s are not differed significantly $(\alpha=P=0.05)$. 
Impact of spray dehydration parameters (inlet/ outlet temperature, feed rate) on physicochemical property of Hibiscus sabdariffa powder

Table 3 and 4 showed the influence of inlet/ outlet temperature, feed rate on physicochemical attributes of roselle calyx powder. Roselle calyx extract should be dehydrated at $140 / 85\left({ }^{\circ} \mathrm{C} /{ }^{\circ} \mathrm{C}\right)$ of inlet/ outlet temperature by 12 $\mathrm{ml} / \mathrm{min}$ of feed rate to obtain the optimal bulk density $0.76 \pm 0.01 \mathrm{~g} / \mathrm{ml}$, solubility $78.25 \pm 0.02 \%$, total phenolic $519.14 \pm 1.08 \mathrm{mg} \mathrm{GAE} / 100 \mathrm{~g}$, total flavonoid $268.65 \pm 0.10 \mathrm{mg}$ QE/ $100 \mathrm{~g}$, anthocyanin $230.07 \pm 0.13 \mathrm{mg} / 100 \mathrm{~g}$. Our present study was similar to other following findings: Al-Kahtani $\mathrm{H}$. A. and Hassan B. H. ${ }^{33}$ manufactured spray-dried powder from extract of roselle (Hibiscus sabdariffa) calyces. They confirmed that the optimal inlet air temperature was noticed at $198.5^{\circ} \mathrm{C}$ to obtain the best protein content, ascorbic acid, and solubility of the spray-dried powder. Gonzalez-Palomares et al. ${ }^{34}$ verified different drying temperatures on the volatile substances and organoleptic property of the roselle (Hibiscus sabdariffa) powder. They concluded that the best powder should be conducted at temperature between $190^{\circ} \mathrm{C}$ and $200^{\circ} \mathrm{C}$. Mohamad et al. ${ }^{36}$ examined the the influence of air temperature of foam mat drying on the kinetics and quality of dehydrared roselle extract. This dehydration technique strongly accelerated the drying rate and maintained the antioxidant capacity and overall acceptance of roselle calyces powder. Reduced drying duration was noticed when high air temperature was applied. Filkova and Mujumdar ${ }^{65}$ confirmed that temperature was not significantly effected at lower feed rate versus low drying rate. Maskat et al. ${ }^{29}$ examined the influence of input temperature $\left(150,160\right.$ and $\left.170^{\circ} \mathrm{C}\right)$ and input productivity (280, 350 and $420 \mathrm{ml} / \mathrm{h}$ ) on the most roselle powder characteristics during spray dehydration. There was significant impact of input temperature and input productivity on recovery, moisture content and overall acceptance. The powder yield was higher with high feed rate but lower with accelerated inlet temperature. However, feed rate did not cause any detrimental effect on the anthocyanin content in roselle powder. Esteban et al. ${ }^{66}$ evaluated the effect of maltodextrin (10-20\%), input temperature $\left(130-150{ }^{\circ} \mathrm{C}\right)$, output temperature $\left(75-85^{\circ} \mathrm{C}\right)$ and spraying speed (22,000-26,000 rpm). The optimal drying operating variable were noticed at $20 \%$ maltodextrin, $130^{\circ} \mathrm{C}$ input temperature, $75^{\circ} \mathrm{C}$ output temperature and $22,000 \mathrm{rpm}$ spraying speed. Audirene et al. ${ }^{67}$ optimized the spray dehydration of jussara pulp with the support of modified starch and whey protein concentrate by input temperature from $140^{\circ} \mathrm{C}$ to $200^{\circ} \mathrm{C}$. The input temperature $170^{\circ} \mathrm{C}$ was recommended. Bednarska and Janiszewska-Turak (68) demonstrated the role of input temperature $\left(160^{\circ} \mathrm{C}, 200^{\circ} \mathrm{C}\right)$; maltodextrin and arabic gum as wall material on anthocyanins, polyphenols and physical powder characteristics received after spray dehydraion. The mixtures of arabic gum: maltodextrin showed a huge potential to obtain an excellent chokeberry powder with high amount of anthocyanin and polyphenol. In another report, high quality of powder was received when outlet air temperature was in the range of $100-110^{\circ} \mathrm{C}^{69}$. High temperature and short time were commonly appplied to preserve unique property of anthocyanin ${ }^{70}$. Temperature was not significantly effective at lowe feed rate ${ }^{71}$.

Table 4. Influence of feed rate $(\mathrm{ml} / \mathrm{min})$ on physicochemical property of Hibiscus sabdariffa powder

\begin{tabular}{lccccc}
\hline Feed rate (ml/min) & 8 & 10 & 12 & 14 & 16 \\
\hline Bulk density (g/ml) & $0.93 \pm 0.00^{\mathrm{a}}$ & $0.84 \pm 0.03^{\mathrm{ab}}$ & $0.76 \pm 0.01^{\mathrm{b}}$ & $0.65 \pm 0.02^{\mathrm{bc}}$ & $0.53 \pm 0.00^{\mathrm{c}}$ \\
Solubility (\%) & $90.04 \pm 0.03^{\mathrm{a}}$ & $83.54 \pm 0.00^{\mathrm{ab}}$ & $78.25 \pm 0.02^{\mathrm{b}}$ & $70.32 \pm 0.00^{\mathrm{bc}}$ & $63.40 \pm 0.03^{\mathrm{c}}$ \\
$\begin{array}{l}\text { Total phenolic } \\
\text { (mg GAE/ 100 g) }\end{array}$ & $484.12 \pm 1.37^{\mathrm{bc}}$ & $496.33 \pm 1.24^{\mathrm{b}}$ & $519.14 \pm 1.08^{\mathrm{a}}$ & $503.23 \pm 1.16^{\mathrm{ab}}$ & $461.08 \pm 1.02^{\mathrm{c}}$ \\
Total flavonoid & $201.57 \pm 0.12^{\mathrm{bc}}$ & $219.57 \pm 0.18^{\mathrm{b}}$ & $268.65 \pm 0.10^{\mathrm{a}}$ & $247.60 \pm 0.17^{\mathrm{ab}}$ & $169.87 \pm 0.11^{\mathrm{c}}$ \\
$\begin{array}{l}\text { (mg QE/ 100 g) } \\
\text { Anthocyanin }\end{array}$ & $164.29 \pm 0.13^{\mathrm{bc}}$ & $187.42 \pm 0.07^{\mathrm{b}}$ & $230.07 \pm 0.13^{\mathrm{a}}$ & $211.50 \pm 0.09^{\mathrm{ab}}$ & $134.22 \pm 0.15^{\mathrm{c}}$ \\
(mg/100g) & & & & & \\
\hline
\end{tabular}

Figures are the mean of three replications; Figures in row followed by the same letter/s are not differed significantly $(\alpha=P=0.05)$. 


\section{CONCLUSION}

Roselle (Hibiscus sabdariffa L.) calyx was brilliant red in colour due to the present of anthocyanins. The consumption of roselle calyx powder could promote health benefits. This research successfully investigated some technical parameters for spray drying roselle calyx extract into dried powder. Sugar alcohols (mannitol, sorbitol, isomalt, xylitol, erythritol), carrier agents (maltodextrin, gum arabic, glutinous starch, whey protein concentrate, carboxymethyl cellulose), operating variables (inlet/ outlet air temperature, feed rate) significantly affected to the physicochemical attributes of the roselle dried powder. The best drying parameters found in the present study were noticed at $8 \%$ isomalt as supplement; $12 \%$ whey protein concentrate as carrier agent; inlet/ outlet air temperature $140 / 85^{\circ} \mathrm{C} /{ }^{\circ} \mathrm{C}$ and feed rate $12 \mathrm{ml} / \mathrm{min}$ as the main operating parameters.

\section{ACKNOWLEDGMENTS}

I would like to express my heartfelt thanks to Dr. Nguyen Hong Tuoi for providing assistance on methods. Thanks to Rainbow Co., Ltd. for providing assistance on bioinformatics analysis. I am grateful to Dr. Lam Thanh Buu for English editing of the manuscript. I would also like to thank Mrs Le Thi Kieu Oanh for the collaboration during the research.

\section{FUNDING}

This study was supported by Thu Dau Mot University, Vietnam.

\section{DATA AVAILABILITY}

All datasets generated or analyzed during this study were included in the manuscript.

\section{ETHICS STATEMENT}

This article does not contain any studies with human participants or animals performed by the author.

\section{REFERENCES}

1. Chen XD, Patel KC. Manufacturing better quality food powders from spray drying and subsequent treatments. Drying Technol. 2008;26(11):1313-1318. doi: 10.1080/07373930802330904

2. Mezzena M, Scalia S, Young PM, Traini D. Solid lipid budesonide microparticles for controlled release inhalation therapy. The AAPS Journal. 2009;11(4):771778. doi: 10.1208/s12248-009-9148-6

3. Bianco S, Caron V, Tajberg L, et al. Modification of the solid-state nature of sulfathiazole and sulfathiazole sodium by spray drying. AAPS Pharm Sci Tech. 2012;13(2):647-660. doi: 10.1208/s12249-012-9792-5

4. Ferrari CC, Germer SPM, Aguirre JM. Effects of spraydrying conditions on the physicochemical properties of blackberry powder. Drying Technol. 2012;30(2):154163. doi: 10.1080/07373937.2011.628429

5. Krishnaiah D, Bono A, Sarbatly R, Nithyanandam R, Anisuzzaman. Optimisation of spray drying operating conditions of Morinda citrifolia L. fruit extract using response surface methodology. J King Saud Univ., Eng Sci. 2015;27(1):26-36. doi: 10.1016/j. jksues.2012.10.004

6. Santhalakshmy S, Bosco SJD, Francis S, Sabeena $M$. Effect of inlet temperature on physicochemical properties of spray-dried jamun fruit juice powder. Powder Technol. 2015;274:37-43. doi: 10.1016/j. powtec.2015.01.016

7. Saikia S, Mahnot NK, Mahanta CL. Effect of spray drying of four fruit juices on physicochemical, phytochemical and antioxidant properties. J Food Process Preserv. 2015;39:1656-1664. doi: 10.1111/jfpp.12395

8. Suzihaque MUH, Abd Hashib S, Ibrahim UK. Effect of inlet temperature on pineapple powder and banana milk powder. Procedia Soc Behav Sci. 2015;195:28292838.doi: 10.1016/j.sbspro.2015.06.401

9. Paim DRSF, Costa SDO, Walter EHM, Tonon RV. Microencapsulation of probiotic jussara (Euterpe edulis M.) juice by spray drying. LWT - Food Sci Technol. 2016;74:21-25. doi: 10.1016/j.Iwt.2016.07.022

10. Shishir MRI, Chen W. Trends of spray drying: A critical review on drying of fruit and vegetable juices. Trends Food Sci Technol. 2017;65:49-67. doi: 10.1016/j. tifs.2017.05.006

11. Chidavaenzi OC, Buckton G, Koosha F, Pathak R. The use of thermal techniques to assess the impact of feed concentration on the amorphous content and polymorphic forms present in spray dried lactose. Int J Pharm. 1997;159(1):67-74. doi: 10.1016/S03785173(97)00272-X

12. Harjunen $\mathrm{P}$, Lehto VP, Valisaari J, Lankinen T, Paronen $P$, Jarvinen $K$. Effects of ethanol to water ratio in feed solution on the crystallinity of spray-dried lactose. Drug Dev Ind Pharm. 2002;28(8):949-955. doi: 10.1081/ DDC-120006427

13. Tan LW, Ibrahim MN, Kamil R, Taip FS. Empirical modeling for spray drying process of sticky and nonsticky products. Procedia Food Sci. 2011;1: 690-697. doi: 10.1016/j.profoo.2011.09.104

14. Dolinsky A, Maletskaya K, Snezhkin Y. Fruit and vegetable powders production technology on the bases of spray and convective drying methods. Dry Technol. 2000;18(3):747-758. doi: 10.1080/07373930008917735

15. Cynthia SJ, Bosco JD, Bhol S. Physical and structural properties of spray dried tamarind (Tamarindus indica L.) pulp extract powder with encapsulating hydrocolloids. International Journal of Food Properties. 2015;18(8):1793-1800. doi: 


\section{$10.1080 / 10942912.2014 .940536$}

16. Minh NP. Various variables in production of dried roselle (Hibiscus sabdariffa L.) calyx herbal tea. Bioscience Research. 2020;17(2):941-947. https://www.isisn.org/ BR17(2)2020/941-947-17(2)2020BR20-109.pdf

17. Lin $\mathrm{HH}$, Chen JH, Wang CJ. Chemopreventive properties and molecular mechanisms of the bioactive compounds in Hibiscus sabdarifa Linne. Curr Med Chem. 2011;18(8):1245-1254. doi: 10.2174/092986711795029663

18. Grace F, Joseph A, Kwabena OK, Samuel LK, Yaw DF. Potential of aqueous extract of Hibiscus sabdariffa calyces as coloring agent in three pediatric oral pharmaceutical formulations. Journal of Applied Pharmaceutical Science. 2014;4(12):001-007. doi: 10.7324/JAPS.2014.41201

19. Ghazala R, Rajni C. A review on phytochemistry and therapeutic uses of Hibiscus sabdariffa L. Biomed Pharmacother. 2018;102:575-586. doi: 10.1016/j. biopha.2018.03.023

20. SallehMN, Runnie I, Roach D, MohamedS, Abeywardena MY. Inhibition of low-density lipoprotein oxidation and up-regulation of low-density lipoprotein receptor in HepG2 cells by tropical plant extracts. J Agric Food Chem. 2002;50(13):3693-3697. doi: 10.1021/jf011593f

21. Ali BH, Al-Wabel N, Gerald B. Phytochemical, pharmacological and toxicological aspects of Hibiscus sabdariffa: A review. J Phytotheray Res. 2005;19(5):369-375. doi: 10.1002/ptr.1628

22. Gaya IB, Mohammad OMA, Suleiman AM, Maje MI, Adekunle AB. Toxicological and lactogenic studies on the seeds of Hibiscus Sabdariffa Linn (Malvaceae) extract on serum prolactin levels of albino wistar rats.

23. Okoro CE. Production of red wine from roselle (Hibiscus sabdariffa) and pawpaw (Carica papaya) using palmwine yeast (Saccharomyces cerevisiae). Nigerian Food Journal. 2007;25(2):158-164. doi: 10.4314/nifoj. v25i2.50854

24. Tsai PJ, Mclntosh J, Pearce P, Camden B, Jordan $B R$. Anthocyanin and antioxidant capacity in roselle (Hibiscus sabdariffa L.) extract. Food Res Int. 2002;35(4):351-356. doi: 10.1016/S09639969(01)00129-6

25. Ismail A, Ikram EHK, Nazri HSM. Roselle (Hibiscus sabdariffa L.) seeds nutritional composition protein quality and health benefits. Food. 2008;2(1):116. http://www.globalsciencebooks.info/Online/ GSBOnline/images/0806/FOOD_2(1)/Food_2(1)1-16o. pdf

26. Bako IG, Mabrouk MA, Abubakar A. Antioxidant effect of ethanolic seed extract of Hibiscus sabdariffa Linn (Malvaceae) alleviate the toxicity induced by chronic administration of sodium nitrate on some haematological parameters in Wistars rats. Adv J Food Sci Technol. 2009;1(1):39-42. https://maxwellsci.com/ print/ajfst/39-42.pdf

27. Bolade MK, Oluwalana IB, Ojo O. Commercial practice of roselle (Hibiscus sabdariffa L.) beverage production: Optimization of hot water extraction and sweetness level. World Journal of Agricultural Sciences. 2009;5(1):126131. http://citeseerx.ist.psu.edu/viewdoc/ download?doi=10.1.1.415.3860\&rep=rep1\&type=pdf
28. Bahaeldeen BM, Abdelatif AS, Abdelhafiz AD. Roselle (Hibiscus sabdariffa L.) in Sudan, cultivation and their uses. Bulletin of Environment, Pharmacology and Life Sciences. 2012;1(6):48-54. https://www.researchgate. net/publication/321759327_Roselle_Hibiscus_ sabdariffa_L_in_Sudan_Cultivation_and_Their_Uses

29. Maskat MY, Lung CK, Momeny E, Khan MJ, Siddiqui SA. Temperature and feed rate effects properties of spray dried Hibiscus sabdariffa powder. Int I Drug Dev Res. 2014;6:28-34. https://www.ijddr.in/drugdevelopment/temperature-and-feed-rate-effectsproperties-of-spray-dried-hibiscussabdariffa-powder. php?aid $=5709$

30. Thongam CA, Rocky T, Sylvia MS, Jenita T, Sanasam SS. Hibiscus sabdariffa - A natural micro nutrient source. International Journal of Advanced Research in Biological Sciences. 2016;3(4):243-248. https://ijarbs. com/pdfcopy/apr2016/ijarbs33.pdf

31. Ochoa-Velasco CE, Salazar-Gonzalez C, Cid-Ortega S, Guerrero-Beltran JA. Antioxidant characteristics of extracts of Hibiscus sabdariffa calyces encapsulated with mesquite gum. J Food SciTechnol. 2017;54:17471756.

32. Archaina D, Vasile F, Jimenez-Guzman J, AlamillaBeltran L, Schebor C. Physical and functional properties of roselle (Hibiscus sabdariffa L.) extract spray dried with maltodextrin-gum arabic mixtures. Journal of Food Processing and Preservation. 2019;43(9):14065. doi: 10.1111/jfpp.14065

33. Al-Kahtani HA and Hassan BH. Spray drying of roselle (Hibiscus sabdariffa L.) extract. Journal of Food Science. 1990;55(4):1073-1076. doi: 10.1111/j.13652621.1990.tb01601.x

34. Gonzalez-Palomares S, Estarron-Espinosa M, GomezLeyva JF, Andrade-Gonzalez I. Effect of the temperature on the spray drying of roselle extracts (Hibiscus sabdariffa L.). Plant Foods Hum Nutr. 2009;64(1):6267. doi: 10.1007/s11130-008-0103-y

35. Mohamad D, Andri CK, Setia BS, Febiani DU. Drying rate and product quality evaluation of roselle (Hibiscus sabdariffa L.) calyces extract dried with foaming agent under different temperatures. Int J Food Sci. 2018;2018:9243549. doi: 10.1155/2018/9243549

36. Cid-Ortega S, Guerrero-Beltran JA. Microencapsulation of Hibiscus sabdariffa (roselle) extracts by spray drying using maltodextrin and gum arabic as carriers. Journal of Food Research. 2020;9(5):53-66. doi: 10.5539/jfr. v9n5p53

37. Navidad-Murrieta MS, Perez-Larios A, SanchezBurgos JA, Ragazzo-Sanchez JA, Luna-Barcenas G, Sayago-Ayerdi SG. Use of a taguchi design in Hibiscus sabdariffa extracts encapsulated by spray-drying. Foods. 2020;9(2):128. doi: 10.3390/foods9020128

38. Singletion VL, Orthofer R, Lamuela-Raventos RM. [14] Analysis of total phenols and other oxidation substrates and antioxidants by means of folin-ciocalteu reagent. Methods Enzymol. 1999;299:152- 178. doi: 10.1016/S0076-6879(99)99017-1

39. Quettier-Deleu C, Gresseier B, Vasseur J, et al. Phenolic compounds and antioxidant activities of buckwheat (Fagopyrum esculentum Moench) hulls and flour. J Ethnopharmacol. 2000;72(1-2):35-42. doi: 10.1016/ 


\section{S0378-8741(00)00196-3}

40. Amr A, Al-Tamimi E. Stability of the crude extracts of Ranunculus asiaticus anthocyanins and their use as food colourants. International Journal of Food Science and Technology. 2007;42(8):985-991. doi: 10.1111/j.1365-2621.2006.01334.x

41. Makkee M, Kieboom APG, Van Bekkum H. Production Methods of d-Mannitol. Starch/Starke. 1985;37(4):136141. doi: 10.1002/star.19850370409

42. Ghoreishi S, Shahrestani RG. Innovative strategies for engineering mannitol production. Trends in Food Science and Technology. 2009;20(6-7):263-270. doi: 10.1016/j.tifs.2009.03.006

43. Bolhuis GK, Rexwinkel EG, Zuurman K. Polyols as fillerbinders for disintegrating tablets prepared by direct compaction. Drug Dev Ind Pharm. 2009;35(6):671-677. doi: 10.1080/03639040802587799

44. Michael AR, Roland HFB. Polyols - more than sweeteners. Sugar Industry. 2013;138:226-234.

45. Yousefi S, Emam-Djomeh Z, Mousavi SM. Effect of carrier type and spray drying on the physicochemical properties of powdered and reconstituted pomegranate juice (Punica granatum L.). J Food Sci Technol. 2011;48(6):677-684. doi: 10.1007/s13197010-0195-x

46. Lewis MJ. Physical properties of foods and food processing systems. Ellis Horwood Ltd.: Chichester, UK. 2018:51-64.

47. Tontul I, Topuz A. Spray-drying of fruit and vegetable juices: Effect of drying conditions on the product yield and physical properties. Trends Food Sci Technol. 2017;63:91-102. doi: 10.1016/j.tifs.2017.03.009

48. Siriporn S, Tiraporn J, Natthaporn C, Pornpimol M, Nadnapang P. Evaluation of physicochemical properties of spray dried bael fruit powder during storage. International Journal of Food Engineering. 2019;5:209213.

49. Kaderides K, Goula AM. Development and characterization of a new encapsulating agent from orange juice by-products. Food Res Int. 2017;100(Pt 1):612-622. doi: 10.1016/j.foodres.2017.07.057

50. Sathyashree HS, Ramachandra CT, Udaykumar N, Mathad PF, Nagaraj N. Rehydration properties of spray dried sweet orange juice. Journal of Pharmacognosy and Phytochemistry. 2018;7(3):120-124. https:// www.researchgate.net/publication/331161166_ Rehydration_properties_of_spray_dried_sweet_ orange juice

51. Mahendran T. Physico-chemical properties and sensory characteristics of dehydrated guava concentrate: Effect of drying method and maltodextrin concentration. Tropical Agricultural Research and Extension. 2010;13(2):48-54. https://pdfs.semanticscholar.org/ c440/68a43781acab880e7ea916e8e4169b5208bb.pdf

52. Chauca MC, Stringheta PC, Sardigna L, CalVidal J. Mango juice dehydration by spray drying using different carriers and functional characterization. Proceedings of the $14^{\text {th }}$ International Drying Symposium, Sao Paulo, Brazil. 2004:205-212.

53. Vaibhav P, Anil KC, Surendra PS. Influence of spray drying technology on the physical and nutritional properties of guava powder. Int I Curr Microbiol App
Sci. 2014;3(9):1224-1237. https://www.ijcmas.com/ vol-3-9/Vaibhav\%20Patil,\%20et\%20al.pdf

54. Jittanit W, Niti-Att S,Techanuntachikul O. Study of spray drying of pineapple juice using maltodextrin as an adjunct. Chiang Mai Journal of Science. 2010;37(3):498-506. http://www.thaiscience.info/ journals/Article/CMJS/10905474.pdf

55. Rodriguez-Hernandez GR, Gonzalez-Garcia R, GrajalesLagunes A, Ruiz-Cabrera MA. Spray drying of cactus pear juice (Opuntia streptacantha): Effect on the physicochemical properties of powder and reconstituted product. Dry Technol. 2005;23:955-973. doi: 10.1080/DRT-200054251

56. Fang Z, Zhang M, Sun Y, Sun J. How to improve bayberry (Myrica rubra Sieb. et Zucc.) juice color quality: Effect of juice processing on bayberry anthocyanins and polyphenolics. J Agric Food Chem. 2006;54(1):99-106. doi: 10.1021/jf051943o

57. Zuhaili I, Ida IM, Mohd RS. Degradation kinetics and color stability of spray-dried encapsulated anthocyanins from Hibiscus sabdariffa L. Journal of Food Process Engineering. 2012;35:522-542. doi: 10.1111/j.1745-4530.2010.00605.x

58. Gradinaru G, Biliaderis CG, Kallithraka S, Kefalas P, Garcia-Viguera C. Thermal stability of Hibiscus sabdariffa $\mathrm{L}$ anthocyanins in solution and in solid state: effects of copigmentation and glass transition. Food Chem. 2003;83(3):423-436. doi: 10.1016/S03088146(03)00125-0

59. Duangmal K, Saicheua B, Sueeprasan S. Colour evaluation of freeze-dried roselle extract as a natural food colorant in a model system of a drink. LWT - Food Sci Technol. 2008;41(8):1437-1445. doi: 10.1016/j. Iwt.2007.08.014

60. Selim KA, Khalil K, Abdel-Bary M, Abdel-Azeim N. Extraction, encapsulation and utilization of red pigments from roselle (Hibiscus sabdariffa L.) as natural food colourants. $5^{\text {th }}$ Alex. Conference of Food and Dairy Science and Technology. Alex. Egypt. 2008.

61. Cristhiane CF, Silvia PMG, Izabela DA, Fernanda $Z V$, Jose MA. Influence of carrier agents on the physicochemical properties of blackberry powder produced by spray drying. International Journal of Food Science and Technology. 2012;47(6):1237-1245. doi: 10.1111/j.1365-2621.2012.02964.x

62. Bhusari SN, Muzaffar K, Kumar P. Effect of carrier agents on physical and microstructural properties of spray dried tamarind pulp powder. Powder Technology. 2014;266:354-364. doi: 10.1016/j. powtec.2014.06.038

63. Tan ND, Thuy NM. Optimization of carriers (maltodextrin, arabic gum) for spray-drying of Pouzolzia zeylanica extracts using response surface methodology. Can Tho University Journal of Science. 2017;6:102-110. doi: 10.22144/ctu.jen.2017.033

64. Varastegani B, Zzaman W, Harivaindaran KV, Yang TA, Abdullah WNW, Lee LK, Easa AM. Effect of carrier agents on chemical properties and sensory evaluation of spray-dried Nigella sativa. CyTA - Journal of Food. 2017;15(3):448-456. doi: 10.1080/19476337.2017.1297960

65. Filkova I, Mujumdar AS. Industrial spray drying systems. 
DIm Mujumdar AS (pynt.). Handbook of Industrial Drying. Ed. 2, New York: Marcel Dekker, Inc. 2015 doi: $10.1201 / \mathrm{b} 17208$

66. Esteban LA, Misael CR, Hector JCV. Influence of maltodextrin and spray drying process conditions on sugarcane juice powder quality. Rev Fac Nal Agr Medellin. 2015;68(1):7509-7520. doi: 10.15446/rfnam. v68n1.47839

67. Audirene AS, Louryval CP, Rafael AO, Vania RNT. Influence of process conditions on the physicochemical properties of jussara pulp (Euterpe edulis) powder produced by spray drying. Braz J Food Technol. 2017;21:2015085. doi: 10.1590/1981-6723.8515

68. Bednarska MA, Janiszewska-Turak $E$. The influence of spray drying parameters and carrier material on the physico-chemical properties and quality of chokeberry juice powder. J Food Sci Technol. 2020;57:564-577. doi: 10.1007/s13197-019-04088-8

69. Tan LW, Ibrahim MN, Taip FS. Empirical model of spray drying of whole milk powder using nozzle atomizer spray dryer. J Food Agric Env. 2010;8(3-4):247-252. doi: 10.1234/4.2010.3027

70. Adams JB, Ongley MH. The degradation of anthocyanins in canned strawberries. Int J Food Sci Technol. 1973;8(3):305-307. doi: 10.1111/j.1365-2621.1973. tb01718.x

71. Filkova I, Mujumdar AS. Industrial spray drying systems. DIm Mujumdar AS (pynt.). Handbook of Industrial Drying. Ed. 2, New York: Marcel Dekker, Inc. 1995. 